\title{
FIRST RECORD OF THE CELLAR SPIDER GENUS NITA HUBER \& EL-HENNAWY, 2007 (ARANEAE, PHOLCIDAE) FROM IRAQ
}

\author{
Ishraq Mohammed Baker Hayder Badry Ali* and Hula Younis Fadhil \\ Department of Biology, College of Science, University of Baghdad, \\ Baghdad, Iraq. \\ *Corresponding author e-mail: hayder.ali1130@yahoo.com
}

Received Date: 02 September 2019, Accepted Date: 09 October 2019, Published Date: 26 December 2019

\section{ABSTRACT}

The current study presents the cellar spiders genus Nita Huber \& El-Hennawy, 2007 (Araneae, Pholcidae) as the first record for Iraq spider fauna, this genus represented by the species Nita elsaff Huber \& El-Hennawy, 2007 were identified based on morphological characteristics and DNA sequence data. A short morphological description is also presented for cellar spiders listed in Iraq; including this species in addition to Artema Atlanta Walckenaer, 1837.

Key words: Araneae, Iraq, Nita, Pholcidae, spiders.

\section{INTRODUCTION}

Family Pholicidae C. L Koch, 1850 is commonly known as cellar spiders or daddy longlegs, vibrating spiders, and other common names, according to their distribution which consists of a large number of manly tropical web-weaving spiders. Cellar spiders are the most diverse and dominant spider groups in the world, the phylogeny of this family has so far been investigated exclusively using morphological data for the family analyzed in a phylogenetic context (Bruvo-Madarić et al., 2005).

According to the World Spider Catalogue (2019) this family encompasses over 1800 species divided into 94 genera; Huber (2011) divided Pholcidae into five subfamilies based on cladistic analyses of morphological and molecular data, Ninetinae Simon, 1890, Arteminae Simon, 1893, Modisiminae Simon, 1893, Smeringopinae Simon, 1893 and Pholcinae. Members of this family show very high ecological plasticity and can be found everywhere from deserts to humid tropical forests. Most of them are distributed and recorded in Asia, Africa and Europe (Huber, 2005).

The main characteristic of this family is having six or eight eyes and three tarsal claws; the anterior median eyes are smallest or absent in six-eyed species, the clypeus is concave and of about the same height as the chelicerae; legs are usually very long with long and flexible tarsi; the carapace is subcircular with the head region often raised. The cheliceraes are relatively weak and fused most of their length (Jocqué and Dippenaar-Schoeman, 2007).

Artema Walckenaer, 1837 is a genus of cellar spiders ,including some of the largest spiders, with most species distributed from northern Africa to the Middle East; although Artema is not 
First record of the cellar spider

a species-rich genus (eleven species) it is widely known due to the widespread synanthropic species Artema Atlanta Walckenaer, 1837 (Aharon et al., 2017).

Nita elsaff Huber and El-Hennawy is the only species of the genus Nita which is monotypic (i.e. a taxonomic group that contains only one immediately subordinate taxon). It is a small-sized spider that inhabits poor habitats in terms of resources; it is difficult to be distinguished and rare in collections (Huber and El-Hennawy, 2007).

This genus was first described in 2007 by Huber and El-Hennawy in Egypt and Uzbekistan and it had also been recorded by Zamani (2017) in Iran. This single species live in arid regions where they shelter under objects close to the soil (Huber and El-Hennawy, 2007).

Spider taxonomy provides a challenging target due to their small size and the difficulties to identify based only on morphology (Barrett and Hebert,2005), it seems to be time consuming and problematic for several reasons and it is difficult or impossible to identify immature spiders due to underdeveloped morphological characters that are useful for species distinction, for example most identification keys are mainly based on the morphology of genitalia of adults, the epigynum in females and the pedipalp in males (Barrett and Hebert, 2005).

In Iraq few studies are recently achieved regarding families Araneae such as Zamani and El-Hennawy (2016), Fomichev et al. (2018), Al-Khazali (2018), Ali et al. (2018), and AlKhazali and Hussein (2019) without listing of Pholicidae, until Al-khazali and Najim (2018) recorded it represented by the species Artema doriae (Thorell, 1881) for the first time in Iraq.

This study aimed to confirm the diagnosis of the species $N$. elsaff using morphological and molecular methods and constructing an identification key to separate the cellar spiders which has been recorded in Iraq.

\section{MATERIALS AND METHODS}

Sampling and morphological identification:

The specimens were collected from different locations of Baghdad, Salahaldeen, and Karbala governorates (Map 1), from November 2018 to June 2019. The specimens were collected by hand using forceps and placed in plastic containers alive separately and then transferred to the laboratory. Captured spiders were preserved in $70 \%$ Ethyl alcohol, examined under binocular (Olympus) stereo microscopesx 10 and photographed with Nikon 20X Field Stereo Microscopes. Morphological identification was carried out using morphological characteristics according to several specific diagnostic keys (Brignoli, 1981; Huber and El-Hennawy, 2007; Aharon et al., 2017). All specimens were deposited in the Iraq Natural History Research Center and Museum, Department of Entomology, University of Baghdad. 


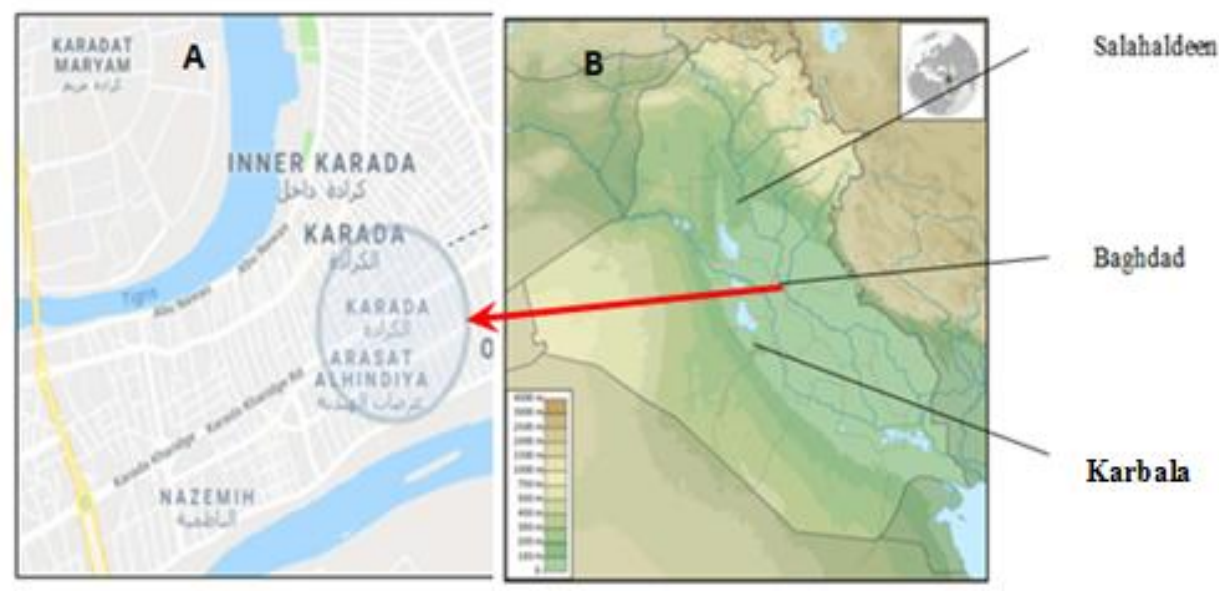

Map (1): Map of collection localities; (A) Nita elsaff in Baghdad province,

(B) Artema atlanta in Salahaldeen and Karbala provinces.

\section{Molecular identification:}

DNA was extracted from the whole spider except the abdomen using the Geneaid DNA Mini extraction Kit for tissue depending on the standard recommended by the manufacturer. The extraction succeeded to obtain whole-genome DNA from the specimens. The gene COI was amplified, and sequenced directly with an automated sequencer;specific primers were used to get and amplify the partial mitochondrial Cytochrome Oxidase subunit I gene (COI), the forward LCO 1490 5'( GGT CAA CAA ATC ATA AAG ATA TTG G)3' (Folmer et al., 1994) with the reverse HCO-700ME 5'( TCA GGG TGA CCA AAA AAT CA )3' (Bork, 2015).

Class Arachnida Cuvier, 1812

\section{RESULTS AND DISCUSSION}

Order AraneaeClerck, 1757

Family Pholcidae C.L. Koch, 1851

Genus: Nita Huber and El-Hennawy, 2007

Nita elsaff, it was first described by B. A. Huber \& H. K. El-Hennawy in 2007.

Materials: Baghdad- Karaada $q, 30$ November 2018, and $\delta \hat{~ i n ~} 2$ December 2018, Arasat $q \hat{o}$, 4 December 2018, the specimens collected from indoors.

Description: Female (Pl. 1A), total length $(2.8-3.0) \mathrm{mm}$, abdomen color is clearly whitecreamy with a little pale-yellow strip on the middle-abdomen which is clothed with dense hairs. legs cylindrical, and relatively equal length 5 or 6 times longer than the body thin and fragile with the length of about $5.8 \sim 6.5$ with flexible and pseudo segments like all most pholicids members. In general the female specimens don't have a distinguishable feature, unmodified clypeus (Huber and Al-Hennawy, 2007).

Males (Pl. 1B): Total length $2.7 \mathrm{~mm}$, carapace width $0.9 \mathrm{~mm}$, legs about $8.5-10 \mathrm{~mm}$, the length of tibia is being variable in each leg, the first leg is the longest I: $10 \mathrm{~mm}$, leg II: 8.5 $\mathrm{mm}$, leg III: $8.9 \mathrm{~mm}$, leg IV: $9.8 \mathrm{~mm}$. Coloration mostly pale ochre-yellow, carapace with a light brown stripe frontally until ocular area, modified distinguished clypeus with strong hairs in the middle, and grey abdomen clothed with smooth hairs. Chelicerae distinctively sclerotized with pair of typical frontal apophyses, the anterior portion of the palp has a clearly 
First record of the cellar spider

visible embolus. All legs have prolateral trichobothrium but there is some ventrolateral trichobothrium on the $1^{\text {st }}$ legs only. Femur, patella, and tibia unmodified. Legs without spines and curved hairs and eight seta like spines on the tarsus with few vertical hairs. A close up view of spider head x10 shows eight eyes arranged in two groups of three closely clustered eyes and two pairs in the middle, usually as in all cellar spiders.
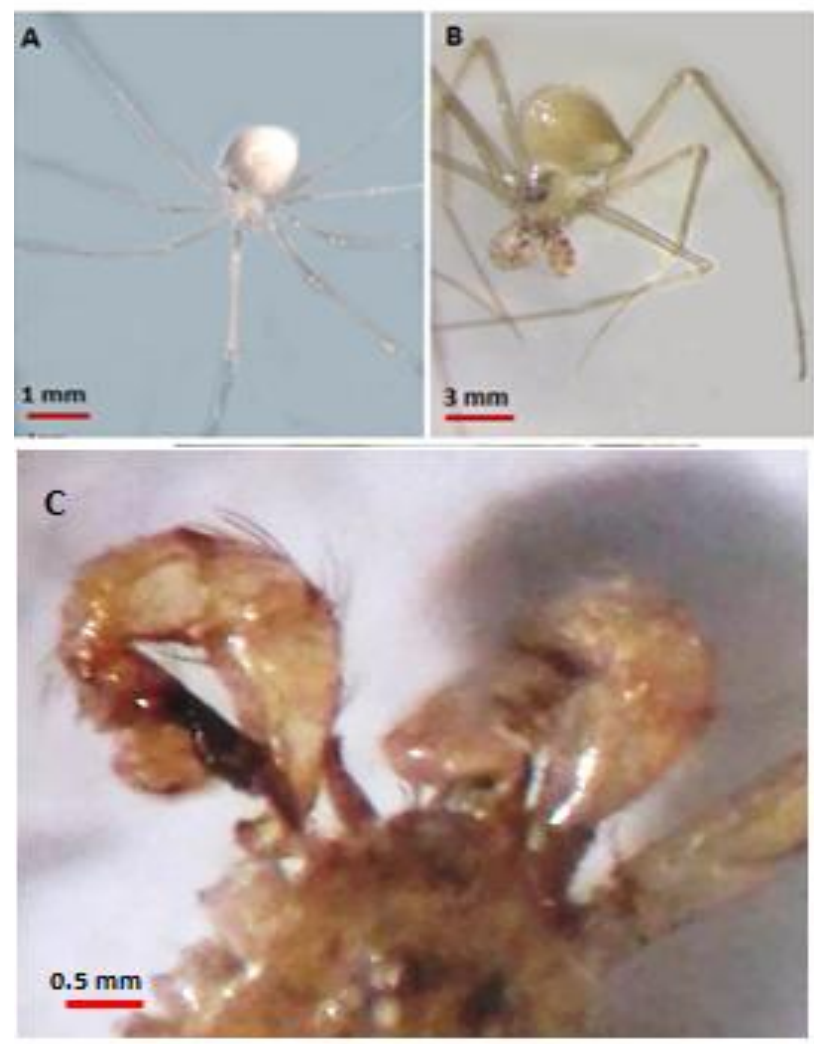

Plate (1): Nita elsaff; (A) Female, (B) Male, (C) Clypeus (retrolateral view).

Comments: This species was previously known from Egypt, Uzbekistan, and recently recorded in Iran (Huber and El-Hennawy, 2007; Zamani et al., 2018). The four specimens were collected from irregular webs, livings mostly inside buildings near the ground with antiquated human objects, the specimen of Al-Arasat is yellowish and the clypeus is significantly noticeable more than the Karada specimens.

Class Arachnida Cuvier, 1812

Order Araneae Clerck, 1757

Family Pholcidae C.L. Koch, 1851

Genus: Artema Walckenaer, 1837 Giant long daddy Artema atlantaWalckenaer, 1837 


\section{Baker et al.}

Materials: Salahaldeen province, Balad,2 $9,1 \delta^{\lambda}$ with juvenile from a building in a farm coordinates of specimens locality area are $34.059^{\circ} \mathrm{N}, 44.0843^{\circ} \mathrm{E}$, elevation $52 \mathrm{~m}(171 \mathrm{ft})$ height, temperature $41{ }^{\circ} \mathrm{C}$ in Summer 17.x.2018.10 specimen from Karbala, 31.x.2018, Karbala province, Karbala city, $32.6068^{\circ} \mathrm{N} / 44.0104^{\circ} \mathrm{E}$.

Description: The largest spider in the family with pantropical distribution (Gao and $\mathrm{Li}$, 2010).

Female: (Pl. 2A) total body length $12 \mathrm{~mm}$, cephalothorax length $5.5 \mathrm{~mm}$, width $3.5 \mathrm{~mm}$, rounded abdomen $6.5 \mathrm{~mm}$ in length, $2.4 \mathrm{~mm}$ width; the first leg is usually the biggest with measurements, , it was $35 \mathrm{~mm}$; whereas the rest of the legs were $30,32.3$ and $33.2 \mathrm{~mm}$ respectively. Circular shape carapace bright brown with a black line runs along from ocular area to the abdomen; the eight eyes are grouped close together on an elevated prominence arranged in two groups of three eyes each and a pair of small anterior median eyes between them (pl. 3D). Thin and extremely long and slender legs with black strip-like rings (Huber and Warui, 2012); seta absent.

Male: Total body length 8.5-9 mm, cephalothorax length $3.5 \mathrm{~mm}$, width $2.8-3 \mathrm{~mm}$, abdomen length 3-3.5 mm , leg measurements: I ( $21.5 \mathrm{~mm}$ ), II ( $19.5 \mathrm{~mm})$, III ( $19.8 \mathrm{~mm})$, IV. (20 $\mathrm{mm})$. Carapace: circular, -brown to yellow with dark and a slightly low area in the center. Heart-shaped sternum with bright color, with clearly visible bases of the legs coxa. Abdomen color is dark brown. Chelicerae with a palpus have an extremely modification in all pedipalp segments (Huber, 2000). In this species the palpal femur (the first obvious segment next to the spider's body) is grossly swollen, large, strong and a useful characteristic for identification purposes. Abdomen is conical shaped and the marking on the specimens varies somewhat such as in other pholcid genera (Beatty et al., 2008), this species characterized by variable colors, spots and dark lines (Al-Abbad et al., 2019). Epigyne half circle with six pairs of spinnerets.

Comments: this species is the biggest of all pholcid species, with a pantropical distribution (Gao and $\mathrm{Li}, 2010$ ). This is the second Artema species that have been recorded from Iraq (Abbad et al., 2019), after the recently described Artema doriae (Thorell, 1881) from Dhi Qar and Basrah province, southern Iraq (Al-khazali and Najim, 2018). 
First record of the cellar spider
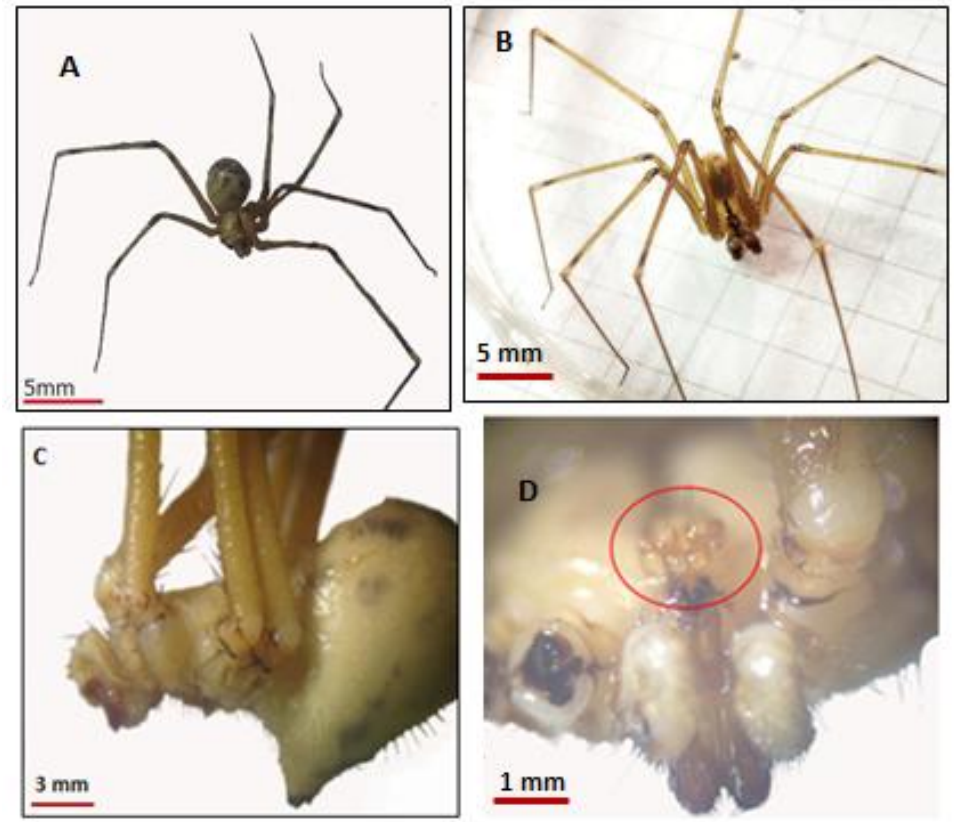

Plate (2): Artema atlanta; (A) Female, (B) Male, (C) Lateral view showing the conical shape of the abdomen, (D) Eyes arrangement.

The results of PCR tests on four spider's specimens of forward LCO and the reverse HCO700ME primers amplify on part of the mtDNA-COI gene with the length about $710 \mathrm{bp}$, two PCR products of the studied spiders were sequenced. The comparison of the studied sequence specimens with deposits (COI) gene copies of the same species in the Gen Bank database showed identity matching (95\%) with the reference species belong to Nita elsaff from Egypt with accession number JX023601.1 (Tab. 1).

Table (1): Summary of data relative to specimens analyzed and accession numbers for the mitochondrial DNA Cytochrome Oxidase I (COI) gene of local and reference specimen of GenBank.

\begin{tabular}{|l|c|c|c|l|}
\hline Organisms & $\begin{array}{c}\text { Accession } \\
\text { no. local } \\
\text { specimen }\end{array}$ & $\begin{array}{c}\text { Accession no. of } \\
\text { reference specimens } \\
\text { of GenBank }\end{array}$ & $\begin{array}{c}\text { Nucleotide } \\
\text { no. of } \\
\text { GenBank }\end{array}$ & Score/Identities \\
\hline Nita elsaff & $\begin{array}{l}\text { MK871348. } \\
1\end{array}$ & JX023601.1 & $38-658$ & $989 /(95 \%)$ \\
\hline
\end{tabular}


Baker et al.

\section{LITERATURE CITED}

Aharon, S., Huber, B. A. and Gavish-Regev, E. 2017. Daddy-long-leg giants: revision of the spider genus Artema Walckenaer, 1837 (Araneae, Pholcidae). European Journal of Taxonomy, 376: 1-57.

Ali, H. B., Fadhil, H. Y. and Baker I. M. 2018. Taxonomic and molecular study of the widow spider genus Latrodectus Walckenaer, 1805 (Araneae: Theridiidae) in Iraq. Pakistan Entomologist, 40(1): 25-29.

Al-Khazali, A. M. and Hussein, A. N. 2019. First record of genus Gnaphosa Latreille, 1804 (Araneae: Gaphosidae) in Iraq. Serket, 16(4): 161-165.

Al-Khazali, A. M. 2018.The first record of family Agelenidae from Iraq (Arachnida: Araneae). Serket, 16(1): 60-65.

Al-khazali, A. M. and Najim, S. A. 2018. First records of Pholcidae (Arachnida, Araneae) from Iraq. Bulletin of the Iraq Natural History Museum, 15 (2): 179-187.

Barrett, R. D. H. and Hebert, P. D. N. 2005. Identifying spiders through DNA barcodes. Canadian Journal of Zoology, 83: 481-491.

Beatty, J. A., Berry, J. W. and Huber, B. A. 2008.The pholcid spiders of Micronesia and Polynesia (Araneae, Pholcidae). Journal of Arachnology, 36: 1-25.

Bork, R. J. 2015 Primer efficacy in the DNA barcoding of spiders. Honors Program Theses, 169pp. Available at: http://scholarworks.uni.edu/hpt/169

Brignoli, P. M. 1981. Studies on the Pholcidae, I. Notes on the genera Artema and Physocyclus (Araneae). Bulletin of the American Museum of Natural History, 170(1): 90-100.

Bruvo-Mađarić, B., Huber, B. A., Steinacher, A. and Pass, G. 2005. Phylogeny of pholcid spiders (Araneae: Pholcidae): Combined analysis using morphology and molecules. Molecular Phylogenetics and Evolution, 37: 661-673.

Folmer, O., Black, M., Hoeh, W., Lutz, R. and Vrijenhoek, R. 1994. DNA primers for amplification of mitochondrial cytochrome coxidase subunit I from diverse metazoan invertebrates. Molecular Marine Biology and Biotechnology, 3(5): 294299.

Fomichev, A. A., Marusik, Y. M. and Koponen, S. 2018. New data on spiders (Arachnida: Araneae) of Iraq. Zoology in the Middle East, 64 (4): 329-339.

Gao, C. X. and Li, S. Q. 2010. Artemaatlanta, a pantropical species new for China (Araneae, Pholcidae). Acta Arachnologica Sinica, 19:11-13.

Huber, B. A. 2000. New world pholcid spiders (Araneae: Pholcidae): a revision at generic level. Bulletin of the American Museum of Natural History, 254: 1-348. 
First record of the cellar spider

Huber, B. A. 2005. The pholcid spiders of Africa (Araneae: Pholcidae): state of knowledge and directions for future research. In: Huber B. A., Sinclair, B. J., Lampe, K. H. (eds.) African Biodiversity: Molecules, Organisms, Ecosystems Springer Verlag, p 181-186.

Huber, B. A. 2011 Phylogeny and classification of Pholcidae (Araneae): an update. The Journal of Arachnology, 39: 211-222.

Huber, B. A. and El Hennawy, H. 2007. On old world ninetine spiders (Araneae: Pholcidae), with a new genus and species and the first record for Madagascar. Zootaxa, 1635: 45-53.

Huber, B. A. and Warui, C. M. 2012. East African pholcid spiders: an overview, with descriptions of eight new species (Araneae, Pholcidae). European Journal of Taxonomy, 29: 1-44. Available at: http://dx.doi.org/10.5852/ejt.2012.29

Huber, B. A., Eberle, J. and Dimitrov, D. 2018.The phylogeny of pholcid spiders: A critical evaluation of relationships suggested by molecular data (Araneae, Pholcidae). ZooKeys, 789(3):51-101.

Jocqué, R. and Dippenaar-Schoeman, A. S. 2007. Spider families of the world ( $2^{\text {nd }}$ edition). Royal Museum for Central Africa, Belgium, 338 pp.

Zamani, A. and El-Hennawy, H. K. 2016. Preliminary list of the spiders of Iraq (Arachnida: Araneae). Arachnida - Rivista Aracnologica Italiana, 6: 12-20. 
Bull. Iraq nat. Hist. Mus.

(2019) 15 (4): 403-411

Nita Huber \& El-Hennawy, تسجيل جديد لعناكب القبو من جنس 2007 من العراق (Araneae, Pholcidae)

$$
\begin{aligned}
& \text { اشراق محمدل باقر ، حيدربدري علي و حلا يونس فاضل } \\
& \text { قسم علوم الحياة، كلية العلوم، جـامعة بغداد، بغداد، العراق. }
\end{aligned}
$$

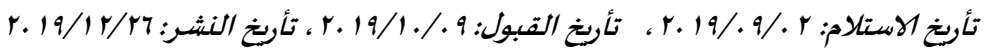

\section{الخلاصة}

قدمت الدراسة الحالية جنس Nita Huber \& El-Hennawy, 2007 من عناكب القبو

Nita Araneae, Pholcidae) elsaff Huber \& El-Hennawy, 2007 وبيانات تسلسل الحامض النووي DNA، مع وصف مختصر للصفات المظهرية لعناكب Artema القبو المدرجة في العراق، شملت الدراسة النوع اعلاه بالإضـافة إلى النوع .atlanta Walckenaer, 1837 